\title{
The uses of Smart Devices in Teaching English for Palestine
}

\author{
Dr. Sumer Salman Abou Shaaban* \\ Associate Professor of e-learning and Teaching Methods Al-Azhar University - Gaza
}

*Corresponding Author: Dr. Sumer Salman Abou Shaaban, Associate Professor of e-learning and Teaching Methods Al-Azhar University - Gaza

\begin{abstract}
This study explored the uses of smart devices among EFL teachers in teaching English for Palestine and find out if there are differences due to gender, years of experience, and teaching level. To fulfill this aim, the descriptive approach was adopted. A questionnaire of (33) uses which was distributed into two main parts (smart phone uses and smart board uses) was utilized to find out the uses of smart devices in teaching English for Palestine. Each part of the questionnaire has two domains: the presentation domain and practice, and feedback one. A sample of (386) EFL teachers was requested to fill out the questionnaire. The Pearson Correlation, Cronbach Alpha, T-test, One Way ANOVA and Scheffe were used to analyze EFL teachers' responses on the questionnaire. The findings showed that EFL teachers sometimes used smart phone and smart board in teaching English for Palestine. There were no statistically significant differences in the uses of smart phone due to gender and teaching experiences but there were differences in the uses due to secondary level in the practice and feedback stage. There were no statistically significant differences in the uses of smart board among EFL teachers due to teaching experiences and there were statistically significant differences due to gender in favor of male teachers and teaching level for the sake of secondary level. The researcher recommended responsible parties to encourage the uses of EFL teachers to smart devices by making competition among teachers, holding workshops for teachers to exchange their experiences.
\end{abstract}

Keywords: smart devices, smart board, smart phone, English for Palestine

\section{INTRODUCTION}

Smart devices are rapidly gaining popularity around the world as an effective way to enhancing the process of teaching/learning foreign/ second language. Rapid evolution of smart devices "has greatly changed every walk of life including language pedagogy, language learning and language use. The introduction of ICT in language teaching has opened new horizons for language teachers to have more interactive and learner-centered classroom environment" (Chou, 2010, p. 32). This is consistent with the new role added to education paradigms, which is meeting "the need for humans to consistently, persistently and effectively integrate their behaviors with digital technological systems" (Yonglin et al, 2013, p.89).

In light of the astonishing developments of smart devices, it is obvious that the smart phone and smart board are the most of these devices adopted in the process of teaching/ learning foreign language. "Mobile Assisted Language Learning has emerged as a potential assistive tool in the complex process of language learning. Technological advances in the last quarter of the last century have made it mandatory for the teachers to employ technology as a tool to help in the process of teaching and learning" Taji et al,( 2016). Jelyani et al (2014) stated, "The integration of smart boards in the foreign language classrooms has caused an impression that the smart boards are an innovative and powerful support for language acquisition. Thus, smart board is recommended to be integrated into the EFL curriculum by means of a careful adaptation of the materials and a systematic training in how to use this type of technology in language classrooms." In the same context, Davidovitch and Yavich (2017) explained that "the efficacy of smart boards depends on wise use by the teacher, with the aim of making the material accessible for the students. Teachers must search how to use smart boards, prepare themselves well for each lesson, and use all the aides available to them."

One thing that should not be overlooked is that the students themselves have a clear passion and high tendencies towards employing smart devices in teaching/ learning (Zayed, 2016). This is what prompted Sharim and Crompton $(2015$, p.301 - 302) to present some advices for teachers to enhance 
adopting smart devices effectively by saying that "they must understand their particular attributes, perceive self-efficacy in using them, have positive attitudes towards their pedagogical affordances and recognize challenges to implementing them in education."

\section{The History OF USING TECHNOLOGY IN TEACHING/ LEARNING LANGUAGE}

The assentation of technology in language teaching/ learning has been past ages, for instance, in the grammar translation method; the teacher and students relied on the earliest type of technology, i.e. blackboard on translating sentences. Later on, they used overhead projectors and early software computer programs for drilling. During the 1970s, audiotaped materials were used in the Audio Lingual method where students had to repeat monotonous pattern drills. In the late 1980s and early 1990s, "due to the emergence of cognitive and sociolinguistic approaches to language teaching along with an emphasis on student engagement with authentic, meaningful and contextualized discourse, there was a full-scale shift in the use of technology in the classrooms" (Baleghizadeh and Oladrostam, 2011).

\subsection{Characteristics of Smart Devices}

According to Le, Nguyen and Barnett (2012) smart devices have the following five fundamental characteristics:

1. Automation: the ability to accommodate automatic devices or perform automatic functions;

2. Multi-functionality: the ability to perform various duties or generate different outcomes;

3. Adaptability: the ability to learn, predict and meet the needs of users;

4. Interactivity: the ability to allow the interaction among users;

5. Efficiency: the ability to perform functions in a convenient manner that saves time and costs.

\subsection{Benefits of using Smart Devices in TEFL}

Which cannot be ignored, is the aesthetic benefits offered by smart devices for the teachers, students and community of learning, which depend primarily on the way they utilized in teaching/ learning. After reviewing the literature critically on the benefits of smart devices, for instance Obari and Lambacher (2014, p.20), Tanveer (2016) Mejia (2016, 80 -82), Baleghizadeh and Oladrostam (2011), Stock well and Hubbard (2013) and Al-Saleem (2013) and for the previous studies presented in the current study, the researcher classified the benefits of using smart devices, in TEFL, into three categories as below:

A. Benefits for EFL teachers, smart devices help EFL teachers to:

- Access to a lot of resources in the shortest time.k2

- Integrate multimedia facilities such as written text, video clips, and soundtracks.

- Save notes, they have written on the board during the class time and reuse it, and record the whole lesson and represent it.

- Maintain effective teaching for the whole class.

- Attract all students' attention and enhance their imagination and creativity.

- Organize information and raise self-efficacy.

- Make the lesson more comprehensive, collaborative and enjoyable.

- Support and enhance a wide range of EFL activities and games.

\section{B. Benefits for students, Smart devices help students by:}

- Increasing a large space of hand-on work with smart devices and multimedia.

- Learning in different ways.

- Increasing the level of students' engagement in a classroom.

- Motivating learners and promoting enthusiasm for learning.

- Creating more fun and more excite activities and games.

- Providing speed and depth learning.

- Recoding the lesson and listening to it when there is a need.

- Asking teachers and getting answers or/ and feedback individually. 


\section{Benefits for Community of Learning, Smart devices support the community by:}

- Changing the traditional nature of the classroom.

- Maintaining enjoyable, creative, and interesting atmosphere.

- Promoting participation and interaction among the students' learning.

- Involving the students in the learning teaching process.

\subsection{Principles of using Smart Devices in Teaching}

Here are some principles presented by Stock well and Hubbard (2013, pp. 8 - 10), Li and Leina (2012, pp. 145-147), and Davidovitch and Yavich (2017) to guarantee the effective and optimal use for smart devices in foreign language teaching:

- Create interesting activities that encourage collaborative work and have a kind of challenges among students either they work individually or in groups.

- Consider flexibility in the procedures of employing technology in a lesson.

- Keep language learning activities short, well-organized and meet students' language level and individual differences.

- Let language learning activities fit the smart device and the learning environment and vice versa.

- Deliver content in the simplest possible format.

- Provide students with suitable guidelines for using the smart device, train students when it is necessary, and push regular reminders and questions.

- Scaffold and support situated learning methods.

- Effective use of smart devices, considering avoid using them extensively.

- Anticipate problems that teachers may face while using smart devices and suggest applicable solutions.

- Choose the suitable smart devices for the lesson in the right time.

\subsection{Procedures for using Smart Devices in TEFL}

By reviewing different related studies such as Ehrhardt-Martinez's, Donnelly and Laitne's (2010), Löfström's (2014), and Davidovitch and Yavich's (2017), the following procedures have been extrapolated to help Palestinian EFL teachers enhance the uses of smart devices in teaching English for Palestine. These procedures must be taken into account by the teachers outside and inside the classroom to ensure the optimal application of smart devices and to facilitate the process of teaching and learning foreign language.

1. Raise awareness and enhance their competency of using smart devices by reading, sharing experiences, following real implementation of smart devices, and consulting experts or technicians for help.

2. Set up a plan with clear steps of implementation considering time of each step, instructions, teacher's role and students' role. The plan should include suitable language activities that consistent with students' language level and English for Palestine textbook.

3. Raise students' awareness of using smart devices and their benefits by explaining how to use them and figure out their importance in language learning.

4. Present the activities or tasks in suitable ways that meet students' level and individual differences and stimulate their interests.

5. Follow up activities by answering students' questions, evaluating their responses, giving correct answers and reinforcing the right responses.

6. Reflect and feedback on the experience by pointing out the strength and weakness points, elaborating the reasons stand behind the strong and weak points, and draw suitable action plan for next use. Here, the teacher can also ask students for feedback.

7. Store the material and develop it for reuse next lesson. 


\subsection{Statement of the Problem}

Using smart devices as tools to facilitate teaching and learning EFL have started to spirit and activate among Palestinian schoolteachers, in teaching different subjects. With this widespread of uses, there is an urgent need to find out how smart devices are used in helping teaching and learning EFL in Palestine in order to know the benefits of the available capabilities and services providing by smart devices. This is what the current study seeks to investigate in order to achieve optimal recruitment of smart devices in teaching/ learning EFL in Palestinian schools.

\section{RESEARCH QUESTIONS AND HYPOTHESES}

The researcher addressed the following questions and hypotheses:

- What are the uses of smart phone in teaching English for Palestine?

- There are statistically significant differences in using smart phone at $(\alpha \leq 0.05)$ among EFL teachers due to some variables: gender (male and female), years of experiences $(0-5,6-10$ and more than 10) and teaching level (primary, preparatory, and secondary).

- What are the uses of smart board in teaching English for Palestine?

- There are statistically significant differences in using smart board at $(\alpha \leq 0.05)$ among EFL teachers due to some variables: gender (male and female), years of experiences (0-5, 6- 10 and more than 10) and teaching level (primary, preparatory, and secondary).

\subsection{Research Purposes}

This research aims at revealing the uses of smart devices in teaching English for Palestine among EFL teachers in the Gaza Strip and showing if there are statistically significant differences in using them among EFL teachers due to gender, years of experience and teaching level. Besides, it aims at presenting some recommendations and suggestions to enhance the uses of smart devices in teaching English for Palestine.

\subsection{Research Significance}

This research investigates the uses of the main recent widespread smart devices, which are smart phone and smart board among EFL Palestinian schools teachers. Besides, it includes different uses of these tools in presentation, practice and evaluation lesson stages. Moreover, the current study is expected to encourage teachers to use smart devices in TEFL in Palestinian schools as well as raise students' awareness to realize the best use of these devices in the teaching and learning process. Finally, the findings can contribute in leading greater improvement in teaching English for Palestine.

\subsection{Terms Definitions}

The researcher adopted the following definitions:

Smart device is "an electronic device, generally connected to other devices or networks via different protocol such as Bluetooth, NFC, $\mathrm{WiFi}$, and $3 \mathrm{Getc}$ that can operate to some extent interactively and autonomously. Several notable types of smart devices are smart phones, tablets, smart watches, smart bands and smart key chains. The term can also refer to advice that exhibits some properties of ubiquitous computing, including- although not necessarily-artificial intelligence" (Wikipedia, 2018).

Smart phone is "mobile phone with highly advanced features. A typical smart phone has a highresolution touch screen display, WiFi connectivity, Web browsing capabilities, and the ability to accept sophisticated applications. The majority of these devices run on any of these popular mobile operating systems: Android, Symbian, iOS, BlackBerry OS and Windows Mobile" (Techopedia Inc, 2018).

Smart Board is "one brand of interactive whiteboard. At its simplest an interactive whiteboard allows you to project an image and interact with it by writing on it or moving it around. The smart board is connected to a computer and works with a projector. The projector displays what is open on the computer and, rather than using a mouse or keyboard (although you can use those also), the smart board is to a touch screen, which allows you to manipulate anything or the screen using your figures. It is similar to how you would use a tablet or iPad. Special pens are included in a smart board to make writings in different colors quick and easy" (Study.co, 2018). 
English for Palestine is the curriculum of teaching English for Palestinian students of grades 1 -12. It is designed by Macmillan and presented by the Palestinian Ministry of Education and higher education. It includes teaching different language skills and sub-skills, which were presented according to the general aims of teaching English for Palestinian students from grade 1-12 (operational definition).

\subsection{Delimitations of the Study}

The study focuses to present the most common use of smart devices especially smart phone and smart board in teaching English for Palestine among EFL teachers in the governmental schools at the Gaza Strip in the academic year (2017/2018).

\subsection{Previous Studies}

Factually, there is a growing body of studies regarding the using of smart devices in the process of teaching/ learning foreign or second language. Below are some related studies:

Hamad (2017) studies the uses of WhatsApp to enhance students' learning of English language. A sample of (36) first level female students' from listening and speaking 1 course in King Khalid University completed a questionnaire. Besides, the teacher completed and observation sheet for students. The results showed that using WhatsApp enhanced students' learning and enthusiasm, developed English skills, enriched vocabulary, and helped students learn from mates' mistakes.

Dogan and Akbarov (2016) examined English teachers' attitudes towards mobile learning. A questionnaire was completed by (159) English teachers in state and private schools and universities in Turkey. The results indicated that most English teachers' had positive attitudes towards the usage of mobile devise in teaching process in their classes.

Hamadneh and Ghazal (2016) explored the attitudes of the male and female teachers of the basic elementary stages towards using smart board in Bani Kinanah Directorate of Education and the relationship of some variables such as sex, academic qualification, and years of experience. A sample of (130) teachers completed a questionnaire of attitudes towards using smart bard. The results revealed that the male and female teachers had high attitudes towards using smart board in teaching and there were no statistically significant differences ascribable to the study variables.

Zayed (2016) designed a number of templates of activities for learning English language through the application of WhatsApp. The researcher reviewed different related literature to find out suitable design for the templates. The teachers can adapt these templates with the textbook, students' interest and integrated skills.

Shraim and Crompton (2015) examined perceptions of the value of integrated smart mobile devices in Palestinian higher education teaching activities. (56) Academic staff of Palestinian Technical University-Khadoorie completed a questionnaire about the physical attributes of smart phone device, self-efficacy, pedagogical affordance and challenges of uses in teaching. The results showed that participates still needed more training in using smart phone device in teaching, they were unaware of the full potential of their functionalities, positive various pedagogical affordances of integrating smart phone device in teaching. Some challenges were presented such as lack of time and lack of experiences and knowledge.

Jelyani et al (2014) described the uses of smart boards in teaching English as a foreign language (EFL) classrooms and showed smart board's role in promoting student engagement and interest in classrooms. The researcher reviewed some of previous studies related to the topic of the study; he concluded that smart boards are innovative and powerful support for EFL acquisition, increase new kinds of learning process, indicate positive effect on students engagement, motivation, learning styles and the capacity of enhancing students' understanding.

Muhammed (2014) determined the impact of mobiles on language learning on the part of English forging language university students. A focus group discussion was carried out to collect the data from learners with different backgrounds and levels of English. The results indicated that all participants used smartphones as mobile tools to improve language learning by adopting a variety of smartphones applications associated with language skills systems and international tests. (99\%) of the participants considered smartphones as an effective mobile resource in the process of English language learning. 
Siegel (2011) explored the influence of smart board technology on student engagement in perception of classroom activities. The researcher examined second graders' on task and off-task behaviors during 30-minute math and science lessons that did and did not include the use of smart board. A questionnaire of different items was used to measure students' perceptions. The results revealed that the use of smart board increased students' on-task engagement and using smart board increased students' attention and participation in the classroom.

\subsection{Commentary on the Previous Studies}

Throughout the presentation of the previous studies, it seems obvious that smart phones and smart boards have a strong role in developing foreign language teaching/learning for different learning stages and purposes. Some studies highlighted the impact of using smart devices on language learning such as: Muhammed's (2014) and Siegel's (2011). Some other studies revealed teachers or students' attitudes towards the use of smart technologies for instance: Hamadneh and Ghazal's (2016) and Dogan and Akbarov's (2016). The findings of the previous studies indicated that there are a positive impact and positive attitudes towards using smart devices in teaching/ learning language. The current study focuses only in revealing the uses of smart board and smart phone in teaching English for Palestine in presentation, practice and feedback stages. In completion of the others' work, the researcher was motivated to conduct this study.

\section{METHODS}

The following procedures were carried out to achieve the aims of the study:

\subsection{Research Design}

To find out the uses of smart devices in teaching English for Palestine, the study adopted the descriptive approach. A sample of (386) EFL teachers filled out the questionnaire. Based on the result of EFL teachers' responses, the researcher offered some recommendations and suggestions to increase the uses of smart devices in teaching English for Palestine.

\subsection{Sampling}

The total number of EFL teachers in the governmental schools of the Gaza Strip is (1363) i.e. (601) males and (762) females. A random sample of total (386) EFL teachers among which (138) male and (248) female participated in this study.

\subsection{The Tool of the Study}

For the purpose of the study, a questionnaire of (33) uses of smart devices in teaching English for Palestine was utilized to find out the uses of smart devices in teaching English for Palestine. It consisted of two main parts: the uses of smart phone and uses of smart board. Each part has two domains: the domain of presentation and the domain of practice and feedback. The teachers should determine the degree of the use of each device by ticking one of the three options Likart-scale (always, sometimes, and rarely). The following table shows the questionnaire domains.

Table1. The Description of the Questionnaire

\begin{tabular}{|l|l|l|l|}
\hline Smart Device & Lesson Stage & No. of Items & Total \\
\hline Smart phone & Presentation stage & 4 & 13 \\
\cline { 2 - 3 } & Practice and feedback stage & 9 & \\
\hline \multirow{2}{*}{ Smart board } & Presentation stage & 13 & 20 \\
\cline { 2 - 3 } & Practice and feedback stage & 7 & \\
\hline Total & & \multicolumn{2}{|l|}{33} \\
\hline
\end{tabular}

\subsection{Validity of the Questionnaire}

Juries' validity and internal consistency were used to ensure the validity of the questionnaire as follows:

Juries' Validity: a panel of EFL Palestinian supervisors, EFL teachers and university professors modified the questionnaire. Some items were rephrased by the juries and two items were deleted because they were included in the other items.

Internal Consistency: to verify the internal consistency, the Pearson correlation coefficient was measured between the score of each item in the part and the total score of the part. 
Table2. Pearson Correlation Coefficient of each Item

\begin{tabular}{|l|l|l|l|l|l|}
\hline No. & $\begin{array}{l}\text { Pearson's } \\
\text { Correlation } \\
\text { Coefficient }\end{array}$ & Significant Level & No. & $\begin{array}{l}\text { Pearson's } \\
\text { Correlation } \\
\text { Coefficient }\end{array}$ & Significant Level \\
\hline 1 & 0.452 & 0.05 & 7 & 0.651 & 0.01 \\
\hline 2 & 0.596 & 0.01 & 8 & 0.452 & 0.05 \\
\hline 3 & 0.495 & 0.05 & 9 & 0.488 & 0.05 \\
\hline 4 & 0.557 & 0.01 & 10 & 0.651 & 0.01 \\
\hline 5 & 0.495 & 0.05 & 11 & 0.465 & 0.01 \\
\hline 6 & 0.725 & 0.01 & 12 & 0.636 & 0.01 \\
\hline 13 & 0.526 & 0.01 & & & \\
\hline
\end{tabular}

As it is clear in table (2), all values of correlation coefficient for the smart phone part were significant at $(0.01$ and 0.05$)$ which proves that the tool is of high internal validity.

Table3. Pearson Correlation Coefficient of each Item

\begin{tabular}{|l|l|l|l|l|l|}
\hline No. & $\begin{array}{l}\text { Pearson's } \\
\text { Correlation } \\
\text { Coefficient }\end{array}$ & Significant Level & No. & $\begin{array}{l}\text { Pearson's } \\
\text { Correlation } \\
\text { Coefficient }\end{array}$ & Significant Level \\
\hline 1 & 0.436 & 0.01 & 11 & 0.645 & 0.01 \\
\hline 2 & 0.555 & 0.01 & 12 & 0.495 & 0.05 \\
\hline K23 & 0.624 & 0.01 & 13 & 0.452 & 0.05 \\
\hline 4 & 0.492 & 0.01 & 14 & 0.497 & 0.01 \\
\hline 5 & 0.310 & 0.05 & 15 & 0.619 & 0.01 \\
\hline 6 & 0.433 & 0.01 & 16 & 0.679 & 0.01 \\
\hline 7 & 0.422 & 0.01 & 17 & 0.555 & 0.01 \\
\hline 8 & 0.451 & 0.05 & 18 & 0.492 & 0.01 \\
\hline 9 & 0.421 & 0.05 & 19 & 0.556 & 0.01 \\
\hline 10 & 0.577 & 0.01 & 20 & 0.565 & 0.01 \\
\hline
\end{tabular}

According to table (3), the coefficient correlation of each item within its part (smart board) is significant at levels (0.01 and 0.05). This means that the questionnaire is valid to be used for the purpose of the study.

\subsection{Reliability of the Questionnaire}

The reliability of the questionnaire was measured by Cronbach Alpha. The reliability for the whole questionnaire was $(0.81)$ and the reliability for the smart phone part was $(0.78)$ while it was $(0.83)$ for the smart board part. It is evident that all Cronbach Alpha Coefficients were higher than (0.75), which indicates that the tool was highly reliable to be applied in this study.

The Scale of judging the responses to the Three Options Likart-Scale

Table4. The Scale of judging the responses to the Three Options Likart-Scale

\begin{tabular}{|l|l|l|l|}
\hline & Always & Sometimes & Rarely \\
\hline Mean & $1-1.66$ & $1.67-2.33$ & $2.34-3$ \\
\hline Relative Mean & $33-55$ & $55-77$ & $77-100$ \\
\hline
\end{tabular}

\subsection{Findings}

\section{A- The Findings of the First Part (Smart Phone)}

- The uses of Smart Phone Among EFL Teachers in Teaching English for Palestine

To find out the uses of smart phone, the researcher analyzed the teachers' responses by calculating the means, standard deviation, and relative weight as shown in the following table:

Table5. Means, Stander Deviation, and Relative Mean for the Uses of Smart Phone

\begin{tabular}{|l|l|l|l|l|}
\hline No. & Statements & Mean & $\begin{array}{l}\text { Std. } \\
\text { Deviation }\end{array}$ & $\begin{array}{l}\text { Relative } \\
\text { Mean }\end{array}$ \\
\hline $\begin{array}{l}\text { A. } \\
\text { I use smart phone in presentation stage for: }\end{array}$ & Presentation & 1.75 & 0.98 & 56.82 \\
\hline 1. & Sending audio-visual or written materials for reparation & 1.70 & 0.96 & 56.82 \\
\hline 2. & Displaying announcement for next lessons & 1.70 & 1.00 & 56.65 \\
\hline 3. & Asking students to read extended tasks/ materials & &
\end{tabular}




\begin{tabular}{|l|l|l|l|l|}
\hline 4. & Asking students to prepare questions & 1.70 & 1.02 & 57.51 \\
\hline Total for the first domain & 6.85 & 3.51 & 57.12 \\
\hline $\begin{array}{l}\text { B. Practice and Feedback } \\
\text { I use smart phone in practice and feedback stage for: }\end{array}$ \\
\hline 5. & Sending activities & 1.73 & 1.04 & 59.76 \\
\hline 6. & Answering students' questions & 1.79 & 1.07 & 57.17 \\
\hline 7. & Sending model answers & 1.72 & 1.08 & 57.17 \\
\hline 8. & Asking students to download specific applications & 1.72 & 1.6 & 59.76 \\
\hline 9. & Discussing common errors & 1.79 & 1.09 & 53.37 \\
\hline 10. & Giving online quizzes & 1.60 & 0.97 & 59.41 \\
\hline 11. & Playing language games & 1.78 & 1.05 & 55.44 \\
\hline 12. & Accessing web sites & 1.66 & 1.05 & 56.30 \\
\hline 13. & Using social media for different teaching/learning English purposes & 1.69 & 1.00 & 57.12 \\
\hline Total for the second domain & 15.48 & 8.27 & 57.32 \\
\hline Total for the whole part & 22.33 & 11.52 & 57.26 \\
\hline
\end{tabular}

Table (5) shows that all relative weights rang between (59.76 - 53.37). It also reveals that item (5) has the highest relative weight i.e. (59.76) and item (9) has the lowest relative weight, which is (53.37). The total relative weight of the responses on the first domain (presentation stage) equals (57.12) while the total relative weight of the responses on the second domain (practice and feedback stage) equals (57.32). The total relative weight of the responses on the uses of smart phone equals (57.26). Upon that, the EFL teachers' responses are "sometimes" to use smart phone in teaching English for Palestine for all the mentioned uses in the questionnaire. The results match the finding of Shraim and Crompton (2015).

- Testing the Hypothesis of Smart Phone uses

Independent samples T-test was used to find out if there were differences due to gender (male and female). One way ANOVA was conducted to find out if there were differences due to years of experiences (0- 5, 6- 10 and more than 10 years) and teaching level (elementary, preparatory and secondary stages). The following tables $(6,7$, and 8$)$ display the results.

Table6. T-test Value and Significant Level between Male and Female EFL Teachers' Responses

\begin{tabular}{|c|c|c|c|c|c|c|c|c|c|c|c|}
\hline t-test for & quality & $\mathrm{Me}$ & & & & & & & & \multicolumn{2}{|c|}{$\begin{array}{l}\text { Levene's } \\
\text { Test for } \\
\text { Equality } \\
\text { of } \\
\text { Variances }\end{array}$} \\
\hline \multirow[t]{2}{*}{ Stage } & \multirow[t]{2}{*}{$\begin{array}{l}\text { Gende } \\
\mathrm{r}\end{array}$} & \multirow[t]{2}{*}{ No } & \multicolumn{2}{|c|}{$\begin{array}{l}95 \% \text { Confidence } \\
\text { Interval of the } \\
\text { Difference }\end{array}$} & \multirow[t]{2}{*}{$\begin{array}{l}\text { Std. Error } \\
\text { Differenc } \\
\text { e }\end{array}$} & \multirow[t]{2}{*}{$\begin{array}{l}\text { Mean } \\
\text { Differenc } \\
\text { e }\end{array}$} & \multirow{2}{*}{$\begin{array}{l}\text { Sig. } \\
(2- \\
\text { tailed } \\
)\end{array}$} & \multirow[t]{2}{*}{$\mathrm{df}$} & \multirow[t]{2}{*}{$\mathrm{t}$} & \multirow[t]{2}{*}{ Sig. } & \multirow[t]{2}{*}{$\mathrm{F}$} \\
\hline & & & Upper & Lower & & & & & & & \\
\hline \multirow{2}{*}{$\begin{array}{l}\text { Presenta } \\
\text { tion }\end{array}$} & Male & $\begin{array}{l}13 \\
8\end{array}$ & $\begin{array}{l}2.2082 \\
0\end{array}$ & .76983 & .36578 & 1.48901 & .000 & 384 & $\begin{array}{l}4.07 \\
1\end{array}$ & \multirow[t]{2}{*}{$\begin{array}{l}.52 \\
5\end{array}$} & \multirow[t]{2}{*}{$\begin{array}{l}.40 \\
4\end{array}$} \\
\hline & $\begin{array}{l}\text { Femal } \\
\text { e }\end{array}$ & $\begin{array}{l}24 \\
8\end{array}$ & $\begin{array}{l}2.2090 \\
0\end{array}$ & .76903 & .36578 & 1.48901 & .000 & $\begin{array}{l}283.25 \\
4\end{array}$ & $\begin{array}{l}4.07 \\
1\end{array}$ & & \\
\hline \multirow{2}{*}{$\begin{array}{l}\text { Practice } \\
\text { and } \\
\text { Feedbac } \\
\mathrm{k}\end{array}$} & Male & $\begin{array}{l}13 \\
8\end{array}$ & $\begin{array}{l}4.5936 \\
3\end{array}$ & $\begin{array}{l}1.1859 \\
4\end{array}$ & .86658 & 2.88978 & .001 & 384 & $\begin{array}{l}3.33 \\
5\end{array}$ & \multirow[t]{2}{*}{$\begin{array}{l}.89 \\
5\end{array}$} & \multirow[t]{2}{*}{$\begin{array}{l}.01 \\
7\end{array}$} \\
\hline & $\begin{array}{l}\text { Femal } \\
\mathrm{e}\end{array}$ & $\begin{array}{l}24 \\
8\end{array}$ & $\begin{array}{l}4.5869 \\
8\end{array}$ & $\begin{array}{l}1.1925 \\
9\end{array}$ & .86228 & 2.88978 & .001 & $\begin{array}{l}287.42 \\
5\end{array}$ & $\begin{array}{l}3.35 \\
1\end{array}$ & & \\
\hline \multirow[t]{2}{*}{ Total } & Male & $\begin{array}{l}13 \\
8 \\
\end{array}$ & $\begin{array}{l}6.7476 \\
6 \\
\end{array}$ & $\begin{array}{l}2.0099 \\
4\end{array}$ & 1.20482 & 4.37880 & .000 & 384 & $\begin{array}{l}3.63 \\
4\end{array}$ & \multirow[t]{2}{*}{$\begin{array}{l}.76 \\
7\end{array}$} & \multirow[t]{2}{*}{$\begin{array}{l}.08 \\
8\end{array}$} \\
\hline & $\begin{array}{l}\text { Femal } \\
\text { e }\end{array}$ & $\begin{array}{l}24 \\
8\end{array}$ & $\begin{array}{l}6.7360 \\
4\end{array}$ & $\begin{array}{l}2.0215 \\
6\end{array}$ & 1.19765 & 4.37880 & .000 & $\begin{array}{l}288.26 \\
9\end{array}$ & $\begin{array}{l}3.65 \\
6\end{array}$ & & \\
\hline
\end{tabular}

The previous table (6) shows that the computed $\mathrm{T}$ is lower than the tabulated $\mathrm{T}$ in the two parts and in the total degree of the questionnaire. Hence, it can be stated that there were no statistically significant differences attributed to the gender. In other words, the uses of the female EFL teachers equal those of the male EFL teachers. This result resembles the findings of Hamadneh and Ghazal (2016). 
Table7. One-Way ANOVA Value and Significant Level among the Teachers' Responses due to Years of Experience

\begin{tabular}{|c|c|c|c|c|c|c|c|}
\hline & & Sum of Squares & df & Mean Square & $\mathrm{F}$ & Sig. & Sig. \\
\hline \multirow[t]{3}{*}{ Presentation } & $\begin{array}{l}\text { Between } \\
\text { Groups }\end{array}$ & 13.055 & 2 & 6.528 & \multirow[t]{3}{*}{2.926} & \multirow[t]{3}{*}{.590} & \multirow[t]{3}{*}{$\begin{array}{l}\text { Not } \\
\text { significant }\end{array}$} \\
\hline & $\begin{array}{l}\text { Within } \\
\text { Groups }\end{array}$ & 4738.820 & 383 & 12.373 & & & \\
\hline & Total & 4751.876 & 385 & & & & \\
\hline \multirow[t]{3}{*}{$\begin{array}{l}\text { Practice and } \\
\text { evaluation }\end{array}$} & $\begin{array}{l}\text { Between } \\
\text { Groups }\end{array}$ & 269.286 & 2 & 134.643 & \multirow[t]{3}{*}{3.703} & \multirow[t]{3}{*}{.139} & \multirow[t]{3}{*}{$\begin{array}{l}\text { Not } \\
\text { significant }\end{array}$} \\
\hline & $\begin{array}{l}\text { Within } \\
\text { Groups }\end{array}$ & 26039.005 & 383 & 67.987 & & & \\
\hline & Total & 26308.290 & 385 & & & & \\
\hline \multirow[t]{3}{*}{ Total } & $\begin{array}{l}\text { Between } \\
\text { Groups }\end{array}$ & 350.553 & 2 & 175.277 & \multirow[t]{3}{*}{3.267} & \multirow[t]{3}{*}{.268} & \multirow[t]{3}{*}{$\begin{array}{l}\text { Not } \\
\text { significant }\end{array}$} \\
\hline & $\begin{array}{l}\text { Within } \\
\text { Groups }\end{array}$ & 50771.001 & 383 & 132.561 & & & \\
\hline & Total & 51121.554 & 385 & & & & \\
\hline
\end{tabular}

The table (7) indicates that the value of calculated ' $\mathrm{F}$ ' is lower than the tabulated ' $\mathrm{F}$ ', which means that there weren't any statistically significant differences due to years of experiences among teachers. In conclusion, the results resemble the findings of Hamadneh and Ghazal (2016).

Table8. One-Way ANOVA Value and Significant Level among EFL Teachers' Responses due to Teaching Level

\begin{tabular}{|c|c|c|c|c|c|c|c|}
\hline & & Sum of Squares & Df & Mean Square & $\mathrm{F}$ & Sig. & Sig. \\
\hline \multirow[t]{3}{*}{ Presentation } & $\begin{array}{l}\text { Between } \\
\text { Groups }\end{array}$ & 71.517 & 2 & 35.758 & \multirow[t]{3}{*}{2.926} & \multirow[t]{3}{*}{.055} & \multirow[t]{3}{*}{ Not significant } \\
\hline & $\begin{array}{l}\text { Within } \\
\text { Groups }\end{array}$ & 4680.359 & 383 & 12.220 & & & \\
\hline & Total & 4751.876 & 385 & & & & \\
\hline \multirow[t]{3}{*}{$\begin{array}{l}\text { Practice and } \\
\text { evaluation }\end{array}$} & $\begin{array}{l}\text { Between } \\
\text { Groups }\end{array}$ & 499.079 & 2 & 249.540 & \multirow[t]{3}{*}{3.703} & \multirow[t]{3}{*}{.026} & \multirow[t]{3}{*}{ Significant } \\
\hline & $\begin{array}{l}\text { Within } \\
\text { Groups }\end{array}$ & 25809.211 & 383 & 67.387 & & & \\
\hline & Total & 26308.290 & 385 & & & & \\
\hline \multirow[t]{3}{*}{ Total } & $\begin{array}{l}\text { Between } \\
\text { Groups }\end{array}$ & 857.624 & 2 & 428.812 & \multirow[t]{3}{*}{3.267} & \multirow[t]{3}{*}{.093} & \multirow[t]{3}{*}{ Not Significant } \\
\hline & $\begin{array}{l}\text { Within } \\
\text { Groups }\end{array}$ & 50263.930 & 383 & 131.237 & & & \\
\hline & Total & 51121.554 & 385 & & & & \\
\hline
\end{tabular}

The table (8) shows that the values of calculated ' $F$ ' are lower than the tabulated ' $F$ ' values for presentation stage and the whole uses of the smart phone, which means that there were not any statistically significant differences due to years of experiences among teachers for the presentation stage. In the other hand, where were statistically significant differences for practice and evaluation stage. To find out the differences in which teaching level, Scheffe was used.

Table9. Scheffe for the Uses of Smart Phone in the Different teaching Levels (Primary, Preparatory and secondary).

\begin{tabular}{|l|l|l|l|l|l|}
\hline & Teaching Level (I) & Teaching Level (J) & Std. Error & Mean Difference (I-J) & Sig. \\
\hline Presentation & Primary & Preparatory & .42308 & -.61310 & .351 \\
\cline { 2 - 6 } & & Secondary & .46781 & -1.12696 & .056 \\
\cline { 2 - 6 } & Preparatory & Primary & .42308 & .61310 & .351 \\
\cline { 2 - 6 } & & Secondary & .43671 & -.51386 & .501 \\
\cline { 2 - 6 } & Secondary & Primary & .46781 & 1.12696 & .056 \\
\cline { 2 - 6 } & & Preparatory & .43671 & .51386 & .501 \\
\hline \multirow{3}{*}{\begin{tabular}{l} 
Practice $\begin{array}{l}\text { evaluation } \\
\text { and }\end{array}$ \\
\cline { 2 - 6 }
\end{tabular}} & Primary & Preparatory & .99350 & .17765 & .984 \\
\cline { 2 - 6 } & Preparatory & Secondary & 1.09855 & -2.43940 & .086 \\
\cline { 2 - 6 } & & Primary & .99350 & -.17765 & .984 \\
\cline { 2 - 6 } & Secondary & Secondary & 1.02552 & -2.61705 & .040 \\
\cline { 2 - 6 } & & Primary & 1.09855 & 2.43940 & .086 \\
\hline
\end{tabular}


The uses of Smart Devices in Teaching English for Palestine

\begin{tabular}{|l|l|l|l|l|l|}
\hline Total & Primary & Preparatory & 1.38647 & -.43545 & .952 \\
\cline { 2 - 6 } & & Secondary & 1.53306 & -3.56636 & .068 \\
\cline { 2 - 6 } & Preparatory & Primary & 1.38647 & .43545 & .952 \\
\cline { 2 - 6 } & & Secondary & 1.43115 & -3.13091 & .093 \\
\cline { 2 - 6 } & Secondary & Primary & 1.53306 & 3.56636 & .068 \\
\cline { 2 - 6 } & & Preparatory & 1.43115 & 3.13091 & .093 \\
\hline
\end{tabular}

Table (9) shows that there were differences in the uses for the sake of secondary level. The mean of the secondary level teachers' uses were $(7.415,17.321$, and 24.736) and these means were the highest means in comparison with the all means of primary, preparatory and the total mean of the whole part.

\section{B- The Findings of the Second Domain (Smart Board)}

- The uses of Smart Board Among Efl Teachers in Teaching English for Palestine

To find out the uses, the researcher analyzed the teachers' responses by calculating means, standard deviation and relative weight as presented in the following table:

Table10. Mean Stander Deviation and Relative Mean for the Uses of Smart Board

\begin{tabular}{|l|l|l|l|l|}
\hline No & Statements & Mean & $\begin{array}{l}\text { Std. } \\
\text { Deviation }\end{array}$ & $\begin{array}{l}\text { Percentage } \\
\text { weight }\end{array}$ \\
\hline $\begin{array}{l}\text { A. } \\
\text { I use smart board in presentation stage for: }\end{array}$ \\
\hline 1. & Writing the objectives of the lesson & 1.64 & 1.26 & 54.58 \\
\hline 2. & Showing key words and their meaning & 1.61 & 1.26 & 53.54 \\
\hline $3 . \quad$ Presenting examples for the target lesson & 1.59 & 1.26 & 52.85 \\
\hline 4. & Writing the form of the structure of the target lesson & 1.55 & 1.23 & 51.64 \\
\hline 5. & Using different smart board tools in explanation & 1.53 & 1.18 & 51.12 \\
\hline 6. & Showing the picture of the lesson or related pictures & 1.62 & 1.30 & 54.06 \\
\hline 7. & Playing the listening material & 1.51 & 1.25 & 50.43 \\
\hline 8. & Playing related videos & 1.61 & 1.26 & 53.71 \\
\hline 9. & Connecting previous and new knowledge & 1.57 & 1.22 & 52.33 \\
\hline 10. & Preparing material for perquisite & 1.61 & 1.24 & 53.71 \\
\hline 11. & Recording and representing lessons & 1.50 & 1.19 & 50.78 \\
\hline 12. & Storing and re-using the lesson materials and activities & 1.52 & 1.15 & 48.36 \\
\hline 13. & Showing practical and active situation for the target lesson & 1.45 & 1.22 & 51.91 \\
\hline Total for presentation uses & 20.32 & 15.09 & 52.09 \\
\hline $\begin{array}{l}\text { B. } \\
\text { I use smart board in practice and feedback stage for: }\end{array}$ & & & \\
\hline 14. & Playing language games & & & \\
\hline 15. & Giving activities for different stages of the lesson & 1.56 & 1.17 & 49.13 \\
\hline 16. & Providing model answers & 1.47 & 1.23 & 51.22 \\
\hline 17. & Giving homework & 1.54 & 1.22 & 52.26 \\
\hline 18. & Giving quizzes & 1.57 & 1.22 & 55.03 \\
\hline 19. & Providing immediate feedback & 1.65 & 1.24 & 55.21 \\
\hline 20. & Writing questions to review classes & 1.66 & 1.24 & 54.51 \\
\hline Total for practice and feedback uses & 1.64 & 1.25 & 54.51 \\
\hline Total & 11.08 & 8.07 & 52.75 \\
\hline
\end{tabular}

The results of table (10) reveals that items (12 and 14) have the lowest relative weight, which equals (48.36 and 49.13). This means that the EFL teachers rarely use smart board in storing and re-using the lesson materials and activities and playing language game. The other items relative weight range between $(54.58-50.78)$. Item (1) has the highest relative weight which equals $(54.58)$. The total relative weight of the responses on the first part (presentation stage) equals (52.09) while the total relative weight of the responses on the second part (practice and feedback stage) equals (52.75). The total relative weight of the responses on the uses of smart board equals (52.37). It means that the EFL teachers sometimes use smart board in teaching English for Palestine.

- Test of Hypotheses Related to the uses of Smart Board

Independent samples T-test was used to find out if there are differences due to gender (male and female). One way ANOVA was used to find out if there are differences due to years of experiences (0- 5, 6- 10 and more than 10 years) and teaching level (elementary, preparatory and secondary stages) as its clear in tables $(10,11,12)$ view the results.

International Journal on Studies in English Language and Literature (IJSELL) 
Table11. T-test Value and Significant Level between Male and Female EFL Teachers' Response

\begin{tabular}{|c|c|c|c|c|c|c|c|c|c|c|c|}
\hline \multicolumn{10}{|c|}{ t-test for Equality of Means } & \multicolumn{2}{|c|}{$\begin{array}{l}\text { Levene's } \\
\text { Test for } \\
\text { Equality of } \\
\text { Variances }\end{array}$} \\
\hline \multirow[t]{2}{*}{ Stage } & \multirow[t]{2}{*}{$\begin{array}{l}\text { Gend } \\
\text { er }\end{array}$} & \multirow[t]{2}{*}{ No } & \multicolumn{2}{|c|}{$\begin{array}{l}95 \% \text { Confidence } \\
\text { Interval of the } \\
\text { Difference }\end{array}$} & \multirow{2}{*}{$\begin{array}{l}\text { Std. } \\
\text { Error } \\
\text { Differen } \\
\text { ce }\end{array}$} & \multirow[t]{2}{*}{$\begin{array}{l}\text { Mean } \\
\text { Differen } \\
\text { ce }\end{array}$} & \multirow{2}{*}{$\begin{array}{l}\text { Sig. } \\
(2- \\
\text { taile } \\
\text { d) }\end{array}$} & \multirow[t]{2}{*}{ df } & \multirow[t]{2}{*}{$\mathrm{t}$} & \multirow[t]{2}{*}{ Sig } & \multirow[t]{2}{*}{$\mathrm{F}$} \\
\hline & & & Upper & Lower & & & & & & & \\
\hline \multirow[t]{2}{*}{$\begin{array}{l}\text { Presentati } \\
\text { on }\end{array}$} & Male & $\begin{array}{l}13 \\
8\end{array}$ & $\begin{array}{l}16.685 \\
79\end{array}$ & $\begin{array}{l}11.023 \\
18\end{array}$ & 1.44002 & $\begin{array}{l}13.8544 \\
9\end{array}$ & .000 & 384 & 9.621 & $\begin{array}{l}.00 \\
0\end{array}$ & $\begin{array}{l}13.49 \\
3\end{array}$ \\
\hline & $\begin{array}{l}\text { Fema } \\
\text { le }\end{array}$ & $\begin{array}{l}24 \\
8\end{array}$ & $\begin{array}{l}16.590 \\
49\end{array}$ & $\begin{array}{l}11.118 \\
49\end{array}$ & 1.39055 & $\begin{array}{l}13.8544 \\
9\end{array}$ & .000 & $\begin{array}{l}313.3 \\
32\end{array}$ & 9.963 & & \\
\hline \multirow[t]{2}{*}{$\begin{array}{l}\text { Practice } \\
\text { and } \\
\text { Feedback }\end{array}$} & Male & $\begin{array}{l}13 \\
8\end{array}$ & $\begin{array}{l}8.8642 \\
3\end{array}$ & $\begin{array}{l}5.8229 \\
3\end{array}$ & .77340 & 7.34358 & .001 & 382 & 9.495 & $\begin{array}{l}.00 \\
0\end{array}$ & $\begin{array}{l}32.44 \\
8\end{array}$ \\
\hline & $\begin{array}{l}\text { Fema } \\
\text { le }\end{array}$ & $\begin{array}{l}24 \\
8\end{array}$ & $\begin{array}{l}8.7874 \\
5\end{array}$ & $\begin{array}{l}5.8997 \\
1\end{array}$ & .73397 & 7.34358 & .001 & $\begin{array}{l}329.2 \\
71\end{array}$ & $\begin{array}{l}10.00 \\
5\end{array}$ & & \\
\hline \multirow[t]{2}{*}{ Total } & Male & $\begin{array}{l}13 \\
8\end{array}$ & $\begin{array}{l}25.519 \\
98\end{array}$ & $\begin{array}{l}16.870 \\
26\end{array}$ & 2.19961 & $\begin{array}{l}21.1951 \\
2\end{array}$ & .000 & 382 & 9.636 & $\begin{array}{l}.00 \\
0\end{array}$ & $\begin{array}{l}23.97 \\
7\end{array}$ \\
\hline & $\begin{array}{l}\text { Fema } \\
\text { le }\end{array}$ & $\begin{array}{l}24 \\
8\end{array}$ & $\begin{array}{l}25.340 \\
58\end{array}$ & $\begin{array}{l}17.049 \\
67\end{array}$ & 2.10710 & $\begin{array}{l}21.1951 \\
2\end{array}$ & .000 & $\begin{array}{l}321.1 \\
72\end{array}$ & $\begin{array}{l}10.05 \\
9\end{array}$ & & \\
\hline
\end{tabular}

The previous table (11) presents that the computed $\mathrm{T}$ is higher than the tabulated $\mathrm{T}$ in all parts and in the total degree of the second domain of the questionnaire. Hence, it can be stated that there were statistically significant differences attributed to the gender for the sack of male EFL teachers. In other words, male EFL teachers use smart board in teaching English for Palestine more than female EFL teachers do.

Table12. One-Way ANOVA Value and Significant Level among Teachers' Responses due to Years of Experience

\begin{tabular}{|c|c|c|c|c|c|c|c|}
\hline & & & df & Mean Square & $\mathrm{F}$ & Sig. & Sig. \\
\hline \multirow[t]{3}{*}{ Presentation } & Between Groups & 327.477 & 2 & 163.738 & \multirow[t]{3}{*}{.718} & \multirow[t]{3}{*}{.488} & \multirow{3}{*}{$\begin{array}{l}\text { Not } \\
\text { significant }\end{array}$} \\
\hline & Within Groups & 87291.964 & 383 & 227.916 & & & \\
\hline & Total & 87619.440 & 385 & & & & \\
\hline \multirow{3}{*}{$\begin{array}{l}\text { Practice and } \\
\text { evaluation }\end{array}$} & Between Groups & 86.511 & 2 & 43.256 & \multirow[t]{3}{*}{.662} & \multirow[t]{3}{*}{.516} & \multirow{3}{*}{$\begin{array}{l}\text { Not } \\
\text { significant }\end{array}$} \\
\hline & Within Groups & 24881.145 & 381 & 65.305 & & & \\
\hline & Total & 24967.656 & 383 & & & & \\
\hline \multirow[t]{3}{*}{ Total } & Between Groups & 709.807 & 2 & 354.904 & \multirow[t]{3}{*}{.668} & \multirow[t]{3}{*}{.513} & \multirow{3}{*}{$\begin{array}{l}\text { Not } \\
\text { significant }\end{array}$} \\
\hline & Within Groups & 202399.849 & 381 & 531.233 & & & \\
\hline & Total & 203109.656 & 383 & & & & \\
\hline
\end{tabular}

Table (12) indicates that the value of calculated ' $\mathrm{F}$ ' is lower than the tabulated ' $\mathrm{F}$ ' which means that there weren't statistically significant differences due to years of experiences among teachers.

Table13. One-Way ANOVA Value and Significant Level among EFL Teachers' Responses due to Teaching Level

\begin{tabular}{|c|c|c|c|c|c|c|c|}
\hline & & $\begin{array}{l}\text { Sum of } \\
\text { Squares }\end{array}$ & df & Mean Square & $\mathrm{F}$ & Sig. & Sig. \\
\hline \multirow[t]{3}{*}{ Presentation } & Between Groups & 8168.813 & 2 & 4084.406 & \multirow[t]{3}{*}{19.689} & \multirow[t]{3}{*}{.000} & \multirow[t]{3}{*}{ Significant } \\
\hline & Within Groups & 79450.628 & 383 & 207.443 & & & \\
\hline & Total & 87619.440 & 385 & & & & \\
\hline \multirow{3}{*}{$\begin{array}{l}\text { Practice and } \\
\text { evaluation }\end{array}$} & Between Groups & 1443.534 & 2 & 721.767 & \multirow[t]{3}{*}{11.690} & \multirow[t]{3}{*}{.000} & \multirow[t]{3}{*}{ Significant } \\
\hline & Within Groups & 23524.122 & 381 & 61.743 & & & \\
\hline & Total & 24967.656 & 383 & & & & \\
\hline \multirow[t]{3}{*}{ Total } & Between Groups & 16675.404 & 2 & 8337.702 & \multirow[t]{3}{*}{17.039} & \multirow[t]{3}{*}{.000} & \multirow[t]{3}{*}{ Significant } \\
\hline & Within Groups & 186434.252 & 381 & 489.329 & & & \\
\hline & Total & 203109.656 & 383 & & & & \\
\hline
\end{tabular}

The data of table (13) present that the value of calculated ' $F$ ' is lower than the tabulated ' $F$ ' for teaching stages and for the whole part which means that there were statistically significant differences 
due to years of experiences among teachers in teaching English for Palestine. To find out these differences due to which teaching level of the three ones, Scheffe test was carried out.

Table9. Scheffe for the Uses of Smart Board in the Different teaching Levels (Primary, Preparatory and secondary).

\begin{tabular}{|l|l|l|l|l|l|}
\hline & Teaching Level (I) & Teaching Level (J) & Std. Error & Mean Difference (I-J) & Sig. \\
\hline Presentation & & & & & \\
\cline { 2 - 6 } & Primary & Preparatory & 1.74313 & 1.73530 & .610 \\
\cline { 2 - 6 } & & Secondary & 1.92743 & -9.17269 & .000 \\
\cline { 2 - 6 } & Preparatory & Primary & 1.74313 & -1.73530 & .610 \\
\cline { 2 - 6 } & & Secondary & 1.79931 & -10.90799 & .000 \\
\cline { 2 - 6 } & Secondary & Primary & 1.92743 & 9.17269 & .000 \\
\hline \multirow{4}{*}{$\begin{array}{l}\text { Practice } \\
\text { evaluation }\end{array}$} & & Preparatory & 1.79931 & 10.90799 & .000 \\
\cline { 2 - 6 } & Primary & Preparatory & .95099 & -.35447 & .933 \\
\cline { 2 - 6 } & & Secondary & 1.05685 & -4.55508 & .000 \\
\cline { 2 - 6 } & Preparatory & Primary & .95099 & .35447 & .933 \\
\cline { 2 - 6 } & & Secondary & .98733 & -4.20062 & .000 \\
\cline { 2 - 6 } & Secondary & Primary & 1.05685 & 4.55508 & .000 \\
\hline \multirow{4}{*}{ Total } & Preparatory & .98733 & 4.20062 & .000 \\
\cline { 2 - 6 } & Primary & Preparatory & 2.67720 & 1.38083 & .875 \\
\cline { 2 - 6 } & & Secondary & 2.97522 & -13.97197 & .000 \\
\cline { 2 - 6 } & Preparatory & Primary & 2.67720 & -1.38083 & .875 \\
\cline { 2 - 6 } & & Secondary & 2.77950 & -15.35280 & .000 \\
\cline { 2 - 6 } & Secondary & Primary & 2.97522 & 13.97197 & .000 \\
\cline { 2 - 5 } & & Preparatory & 2.77950 & 15.35280 & \\
\hline
\end{tabular}

The previous table (14) indicates that there were differences in the mean of smart devices uses for the sake of secondary level teachers. The mean of the secondary level teachers' uses were (27.698, 14.250, and 42.192) and it is worth mentioning that these means were the highest means in comparison with means of primary, preparatory and the total mean of the whole part.

\section{DISCUSSION}

The results of the uses of smart phone and smart board showed that EFL teachers' responses were most in sometimes in the Likart-Scale. The researcher refers this result for the following reasons:

- The degree of uses was sometimes for all uses this indicates that there were a level of awareness and efforts from the responsible in the ministry of education in enhancing the uses of ICT and smart devices in teaching English for Palestine. Although, these efforts still need more and more to motivate the EFL teachers adopt smart devices in their teaching.

- Electricity problem stands as the main reason for this result. This is because electricity works nearly $(3-5)$ hours daily in the Gaza Strip.

- The burden of teachers on many tasks to be accomplished prompted teachers to ignore the employment of smart devices. The required effort and time to optimize the use of these smart devices cannot be ignored, especially when employed for the first time.

- The EFL teachers did not find sufficient motivation from officials in the school or the ministry of education to employ these smart devices effectively in the teaching English for Palestine, for example there were not competitions between teachers or hold workshops for the presentation of successful experiences.

- The deteriorating economic situation in the Gaza Strip has not allowed many schools to provide smart boards in every classroom. In addition, there is no smart phone available with all students and sometimes with the teacher him/ herself. Further, there is no internet access for many students and teachers homes.

- Some EFL teachers have negative attitudes towards employing smart devices in teaching English for Palestine, and others have not had the skills to employ them. On the other hand, it is noticeable that some students have a negative trend as well as poor skills in the uses of smart devices. Yonglin et al (2013, p.89) mentioned that "educators must also begin to consider how effectively to use new technologies to their capacity while, at the same time, training learners in cognitive skills that allow them to do the same." 
- It is difficult to train all students and teachers on the use of smart devices in serving teaching/ learning specially these times in the Gaza Strip for political and economic reasons.

- The poverty of the educational environment in supporting EFL teachers with successful practical experiences in employing smart devices in teaching English for Palestine.

- Weak contact between teachers and experts as well as experts with teachers to discuss how to enhance the uses of smart devices in teaching English for Palestine.

- Lack of continual feedback on the uses of smart devices to enhance their uses teaching English for Palestine.

This confirms with Shraim and Crompton (2015) opinions when they said that smart phones, "becoming increasingly ubiquitous among educators and students in Palestine. While their use in on the rise, many academics are not effectively incorporating this technology into teaching, which may be attributable to their negative perception of these devices." In addition the previous mentioned reasons confirms with Tanveer (2016), he mentioned that "however, the challenges like technological illiteracy, extremely limited educational background of some students, lack of time and digital resources, lack of confidence to use digital equipment, untrained lecturer, etc. act as barriers to cause the full potential of ICT to remain untapped. In order to enhance the efficacy of ICT learning environment, teachers and students must be provided ample support in terms of training, equipment and time resources."

The results of testing the differences of the study variables showed that there were no statistically significant differences in the uses of smart phone due to gender and teaching experiences but there were statistically significant differences in the uses due teaching level for the sake of secondary level. There were no statistically significant differences in the uses of smart board due years of experiences and there were statistically significant differences in the uses due gender for the sake of male teachers and due to teaching level for the sake of secondary level in all lesson stage in the uses of smart board. These results could be imputing to the reasons below:

- It is known that male teachers spend more time in dealing with the Internet because they may have more free time out of school time. This may help them to understand how to use the smart board more by watching videos that explain the mechanism of the use. Besides, as is generally observed, males tend to use technological devices more than females.

- Teaching secondary students depends on abstractions rather than sensibilities, which has made teaching aids more difficult to use in teaching English. Therefore, the use of smart devices has resulted in the activation of teaching and learning English for this stage and more modernly. In primary and preparatory levels, teachers find many appropriate tools for this age group, which can be used in a proper manner and appropriate to the characteristics of students and activate teaching/ learning English.

- It is noticeable in these days that all age groups in Palestinian society have the basic skills of using smart devices as one of the requirements of the area. In turn, there were no statistically significant differences due to years of experience among teachers.

\section{RECOMMENDATIONS AND SUGGESTIONS}

Based on the findings, the following recommendations were directed for teachers, supervises, and researchers:

- Conduct training courses and workshops revolve on how to operate smart devices in EFL classes.

- Provide students with guidelines for using smart devices logically and take the advantages of these smart devices in learning process.

- Connect Palestinian EFL teachers with other teachers in different countries to exchanges experiences of using smart devices in teaching/ learning FL.

- Provide teachers with suitable resources that guiding them to use smart devices in teaching/ leaning process.

- Create templates for using smart phone in teaching/ learning English for Palestine.

- Supply schools with more smart boards to work on finding smart board in each classroom. 
- Do more researches in the use of smart devices in teaching specific language skills and/ or create frameworks for teaching and learning English for Palestine lessons.

\section{REFERENCES}

[1] Al-Saleem, B. (2013). "The Interactive Whiteboard in English as a Foreign Language (EFL) Classroom", European Scientific Journal.8, 3, pp.126-134

[2] Baleghizadeh, S. \& Oladrostam, E. (2011). The Effect of Mobile Assisted Language Learning (MALL) on Grammatical Accuracy of EFL Students, the Internet and Technology in EFL/ESL, Vol. 34 No. 2.

[3] Chou, C, C. (2010). Students' Perceptions and Pedagogical Applications of e-Learning Tools in Online Course. IGI Global, pp. 524-525.

[4] Davidovitch, N. \& Yavich, R. (2017). "The Effect of Smart Boards on the Cognition and Motivation of Students", Higher Education Studies; Vol. 7, No. 1; https://files.eric.ed.gov/fulltext/EJ1135741.pdf

[5] Dogan, A. \& Akbarov, A. (2016). "Teachers' Attitudes towards the Usage of Mobile Devices in EFL Classroom. European Journal of Educational Research, 5 (1), 11-17. Doi:10.12973/eu-jer.5.1.11.

[6] Ehrhardt-Martinez, K.; Donnelly, K.A.; Laitne, J. (2010). "Advanced Metering Initiatives and Residential Feedback Programs: A Meta-Review for Household Electricity-Saving Opportunities": American Council for an Energy-Efficient Economy, Washington, DC, USA.

[7] Hamad, M. M. (2017). "Using WhatsApp to Enhance Students' Learning of English Language: Experience to Share", Canadian Center of Science and Education: Higher Education Studies, Vol. 7, and No. 4.

[8] Hamadneh, Q. M. \& Ghazal, A. A. (2016). "The Trends of the Male and Female Teachers of the Basic Elementary Stages Towards Using the Smart Board in Bani Kinanah Directorate of Education", Journal of Education and Practice, Vol. 7, No. 33. Retrieved January 15 ${ }^{\text {th }}, 2018$ from www.iiste.org

[9] Jelyani, S. J., et al (2014). "Integration of Smart Boards in EFL Classrooms", International Journal of Education \& Literary Studies, Vol. 2, No. 2 http://www.academia.edu/12377438/Integration_of _Smart_Boards_in_EFL_Classrooms

[10] Le, Q.: Nguyen, H and Barnett, T. (2012). "Smart Homes for Older People: Positive Aging in a Digital World". Future Internet, 4, 607-617. http://www.mdpi.com/1999-5903/4/2/607

[11] Li, L. and Leina, L. (2012). "Designing Principles of Mobile Learning in ESP Course for Chinese Students" SciVerse ScienceDirect. Pp. 142 - 148. https://ac.els-cdn.com

[12] Löfström, E. (2014). "Smart Meters and People Using the Grid: Exploring the Potential Benefits of AMRtechnology", Energy Procedia, 58, 65-72. https://www.sciencedirect.com/science/article/pii/S18766 10214017779?via\%3Dihub

[13] Mejía, G. (2016). "Promoting language learning: The use of m-Learning in the Spanish Classes", Revista de Lenguas para Fines Específicos 22.1, pp. 80-99

[14] Muhammed, Z. A. (2014). "The Impact of Mobiles on Language Learning on the Part of English Foreign Language (EFL) University Students", Procedia- social and Behavioral Sciences, Vol. 136, pp. $104-108$. Retrieved May $28^{\text {th }}, 2018$ from www.sciencedirect.com

[15] Obari, H. \& Lambacher, S. (2014). "Impact of a Blended Environment with m-Learning on EFL Skills". Edited by Sake Jager, Linda Bradley, Estelle J. Meima, and Sylvie Thouësny. Research-publishing.net: Dublin,

[16] Shraim, K. \& Crompton, H. (2015). "Perceptions of Using Smart Mobile Devices in Higher Education Teaching: A Case Study from Palestine", Contemporary Educational Technology, 6 (4), pp. 301-318. https://files.eric.ed.gov/fulltext/EJ1105758.pdf

[17] Siegel, K. M. (2011). "Integration of Smart Board Technology and Effective Teaching", Journal on School Educational Technology, Vol.7, No. 1,

[18] Stockwell, G., \& Hubbard, P. (2013). "Some Emerging Principles for Mobile-Assisted Language Learning. Monterey, CA: The International Research Foundation for English Language Education. Retrieved from http://www.tirfonline.org/english-in-the-workforce/mobile-assisted-language-learning

[19] Study.com (2018). What is a SMART Board? Retrieved January $10^{\text {th }}$, 2018 from http://study.com/ academy/lesson/what-is-asmat-board.html

[20] Taji, I. H. et al (20106). "Impact of Mobile Assisted Language Learning (MALL) on EFL: A MetaAnalysis", Advances in Language and Literary Studies, Vol. 7 No. 2.

[21] Tanveer, M. (2016). "Integrating E-learning in Classroom-based Language Teaching: Perceptions, Challenges and Strategies", International Conference, ICT for Language Learning, 4th edition

[22] Techopedia Inc (2018). Terms of Use. Retrieved January $10^{\text {th }}$, 2018 from www.techopedia.Com /definition/2977/smartphone

[23] Yonglin, L. et al (2013). "The Logical Framework of 1:1 Digital Learning" Teachers Talk About What's Important: Papers from 2012 International Teacher Education Dialogue Conference, Jake Madden \& Richard Smith (editors), The Primrose Hall Publishing Group: Australian. 
[24] WIKIPEDIA (2018). Smart Devices. Retrieved January $15^{\text {th }}$, 2018 from https://en.Wikipedia .org/wiki/Smart_device

[25] Zayed, N. M. (2016). "Special Designed Activities for Learning English Language through the Application of WhatsApp", English Language Teaching, vol.9, No.2, p.199. Retrieved May 30 2018 from http://dx.doi.org/10.5539/elt.v9np199

Citation: Sumer Salman Abou Shaaban. The uses of Smart Devices in Teaching English for Palestine "International Journal on Studies in English Language and Literature (IJSELL), vol 8, no. 2, 2020, pp. 8-22. doi: http://dx.doi.org/10. 20431/2347-3134. 0802002

Copyright: (C) 2020 Authors. This is an open-access article distributed under the terms of the Creative Commons Attribution License, which permits unrestricted use, distribution, and reproduction in any medium, provided the original author and source are credited. 